\title{
Learning to Escape: Prison Education, Rehabilitation and the Potential for Transformation
}

\author{
CORMAC BEHAN \\ Centre for Criminological Research, University of Sheffield, England
}

\begin{abstract}
This article examines motivations behind participation in education based on interviews with Irish prisoners. It begins by considering the relationship between education and rehabilitation, especially the latter's re-emergence in a more authoritarian form. Drawing on results from the research, this article argues that the educational approach, culture and atmosphere are particularly important in creating a learning environment in prison. It makes the case that educational spaces which allow students to voluntarily engage in different types of learning, at their own pace, at a time of their choosing, can be effective in encouraging prisoners to engage in critical reflection and subsequently, to move away from criminal activity. It locates education in prison within a wider context and concludes that while prison education can work with, it needs to distinguish itself from, state-sponsored rehabilitation programmes and stand on the integrity of its profession, based on principles of pedagogy rather than be lured into the evaluative and correctional milieu of modern penality.
\end{abstract}

Keywords: Prison education; transformation; rehabilitation; Ireland.

\section{Introduction}

Education within prison is as old as the institution itself. Much debate has been generated about the emergence of the modern prison and its desire to punish, control and discipline (Foucault, 1977; Ignatieff, 1978; Morris and Rothman, 1998), but at its inception there seemed to be some convergence in the objectives of the modern prison and pedagogy: personal change and transformation of the individual, essentially a form of what is loosely termed today as "rehabilitation". Prison education historians Gehring and Eggleston (2007) suggest that the "transformation of prisons into schools is an historic theme in prison reform" dating back over two hundred years to the beginning of the modern prison, which began as an "expression of Western civilisation's humanistic dream". They conclude that "correctional education and prison reform share the same goals: to reform prisons and prisoners" (p.2).

While today's prison educators are likely to support penal reform in its widest sense, the objective of this article is to examine if there is potential for personal reform and transformation in the contemporary prison. The first part examines the concept of rehabilitation, as it has been downgraded and latterly re-emerged. Utilising Rotman's (1986) typology of "authoritarian" and "anthropocentric" models of rehabilitation, it argues that the latter (although not in widespread use) has much in common with the objectives of prison education, based on an adult education approach which encourages critical thinking, reflection and personal awareness. The second section considers findings from interviews with prisoners about their motivation behind, and experiences of, education. Drawing on these results, it concludes with an argument in favour of prison education distinguishing itself from the disciplinary objectives of the prison and correctional goals of authoritarian rehabilitative programmes, and maintaining educational integrity in an era of performance indicators when many seek to define its utility on the basis of non-pedagogical objectives.

\section{Rehabilitation and Education}

Rehabilitation has gone through many manifestations over the centuries, including penitentiary, therapeutic, social learning and rights orientated models (Rotman, 1990). Since the fallout from the publication of Martinson's What Works? (1974), rehabilitation has declined and is no longer the overarching objective of the prison system (Garland, 2001). However rehabilitation has evolved and survived, and to gain acceptance in the late-modern era, there has been a blurring of punitive and rehabilitative discourses, with its reinvention "as punishment" (Robinson, 2008, p.438; emphasis in original). Contemporary rehabilitation practice has moved from viewing the objective as successful reintegration after incarceration to managing risk and social control in the interests of the general public (Crewe, 2012). Political parties that pride themselves on strong law and order policies have proudly embraced a "rehabilitation revolution," not with the avowed objec- 
tive of reintegration, but based on ideas around reducing cost, lowering crime and increasing public confidence in the penal system (Grayling, 2012). On the ascendancy in the $21^{\text {st }}$ century is a form of "authoritarian" rehabilitation that seeks to mould the prisoner into a pre-determined pattern of thought to ensure conformity (Rotman, 1990).

Contemporary approaches to rehabilitation include the Good Lives model (Ward \& Maruna, 2007), Enhanced Thinking Skills (Ministry of Justice, 2010) and Reasoning and Rehabilitation (R\&R) (Ross, Fabiano \& Crystal, 1988; Ministry of Justice, 2010). While many Offender Behaviour Programmes (OBP) have been criticised as seeking to revive the treatment model of rehabilitation (for a discussion, see Robinson and Crow, 2008, pp.119-123), Rotman (1986) distinguishes between "anthropocentric" and "authoritarian" models of rehabilitation. The latter is "a subtle version of the outdated model of corrections." This form of rehabilitation has been "downgraded to a mere instrument of institutional discipline and tends to resort to brainwashing methods" (p.1026). However, the former paradigm which is a "liberty-centred notion of rehabilitation" that is "clearly detached from the disciplinary goals of the institution" (Rotman, 1986, p.1038), has much in common with an adult education approach, as advocated in Irish prison education (Costelloe \& Warner, 2008; Irish Prison Service, 2011). Both seek to respect the independence of the individual, recognise them as agents in the process of change, understand the social and cultural factors of deviance, are cognizant of the impact of incarceration, and do not seek conformity to a prescribed pattern of thought or behaviour (Council of Europe, 1990; Rotman, 1990). They do not overemphasise or pathologize individual activity but seek to understand actions in wider social, political and economic contexts.

An adult education framework promotes, among other elements, transformative learning. It begins with critical thinking, which is not an abstract, rarefied academic process but an activity embedded in the contexts of adults' everyday lives (Brookfield, 1987, p.228). Mezirow (1996) suggested that critical reflection is essential for transformative learning. It may be achieved by (a) extending or refining our terms of reference on issues in society; (b) learning new ones; or (c) transforming our existing frames of reference. It requires changing the context of a problem, or the way we analyze an issue, event or text. This would seem to concur with the anthropocentric model of rehabilitation, which assumes that "significant change can only result from the individual's own insight and uses dialogue to encourage the process of self-discovery." This approach does not "rely on idealistic preaching" but "seeks to awaken in inmates a deep awareness of their relationships with the rest of society, resulting in a genuine sense of social responsibility" (Rotman, 1986, p.1026).

Within many prison systems, education is advocated as one of the key elements in the process of change and transformation (Wright, 2008). Education in prison is considerably wider than traditional classroom activities and while a schoolroom may provide the space where formal learning takes place, as in all educational processes, the significance of the activity may be realised at other times and in different situations. This article, based on interviews with prisoners in Ireland, builds on studies conducted with prisoners in other jurisdictions (see Davidson, 1995; Duguid, 2000; Hughes, 2009; MacGuinness, 2000; Reuss, 1999; Wilson, 2007). It considers whether the potential for personal change and transformation in penal environments is possible through an adult educational approach that distinguishes itself from the disciplinary goals of the institution and the correctional objectives of authoritarian rehabilitation.

Some studies have been undertaken in Ireland that will be hopefully disseminated widely (Carrigan, 2012; Cleere, 2013; Wallington, 2014) but little has been published so far about the motivations for students' participation in education (for higher education, see Costelloe, 2003 and O'Donnell, 2013). Research in other jurisdictions found that students participated in education to develop a new sense of self and mould new identities (Hughes, 2009; Reuss, 1999). MacGuinness (2000) identified 19 different reasons why individuals participated in education. Wilson (2007) discovered that student participation had less to do with formal learning and more to do with the maintenance of their outside social identity. Reuss (1999) found that it was possible for a new self to emerge in the prison environment, and that "the potential exists for personal development and possibly a change in offending behaviour" (p.117). The example of Malcolm X is often used to show prison education as "a dramatic example of prisoners' ability to turn their incarceration into a transformative experience" (Davis, 2003, p.56). In some institutions, educational activities encouraged civic activity and responsibility among prisoners (Behan, 2008); in others, it fostered a more democratic ethos within the prison regime (Duguid, 2000; Eggleston \& Gehring, 2000). The next section examines the motivations for participation in education among a group of Irish prisoners.

\section{Motivations for Participation in Educational Programmes}

This section is primarily based on data from a wider research project examining prisoners' civic engagement. There were 50 interviewees in one institution in Dublin, Ireland. The prison is for adult males over 18 years of age. There were approximately 150 prisoners in the institution at the time of the research and of the 50 interviewees, 46 gave their permission to be tapedrecorded. The interviews were semi-structured and they took place in the prison school. After establishing from a range of options the educational level of interviewees (and whether this was achieved inside or outside the prison), open-ended questions gave respondents the opportunity to explain their motivation/s for attending the school or their reason for not doing so. It was not possible to access prison records to select prisoners randomly, so potential interviewees were approached in 
the school, workshops, shop queues and recreation areas. While the objective was to offer all prisoners the opportunity to participate in this study, over 90 per cent of the prison population were discussed with, provided a reason or rationale for the study and asked to partake in the interviews. Participation was voluntary and no inducements were offered.

A briefing session was undertaken with potential participants beforehand and informed consent was obtained, in writing, from all interviewees. Conscious of making sure consent was informed, especially among those with learning difficulties, the literacy teachers were conferred with about the possibility of their attending the discussion of the consent form if requested by the interviewee. This was to ensure informed consent for those who may have had difficulty understanding the form and the wider research process. This was taken up on one occasion. I was aware that the participant had learning difficulties and was careful not to undermine his integrity. In this instance, his literacy teacher sat in during the explanation of the project and guidelines for the research, and signing of the consent form.

The prison has a very active school and it is central to the programmes and activities available to prisoners. Students are not mandated to attend school. They do so voluntarily. The vast majority of interviewees $(n=45)$ were attending school and four others had done so in the past. The age of the respondents ranged from 22 to 75 years. The majority of interviewees for this study were serving long sentences. Nearly 20 per cent $(n=9)$ were serving a sentence of over 10 years and 40 per cent $(n=20)$ were serving life sentences. A recent review of prison education for the European Commission (GHK, 2012) found that "prisoners are more likely to participate (or be facilitated to participate) in education and training if they are young, serving a long sentence, or based in a large prison" (p.66). Given the length of sentences and the centrality of the school in the daily life of the prison, it is perhaps understandable that so many interviewees were participating in education. All names used are pseudonyms.

While undertaking this research I was on a sabbatical from a teaching position in prison. In recognition of how my previous position may have impacted on the research, it made overcoming the "gatekeepers" (which in prison can be many and frustrating) an easier process. In response to "whose side are we on?" (Becker, 1966), I was undoubtedly empathetic to the endeavours of prisoners as they engaged in education. Nevertheless, that should not necessarily skew the outcome as it is virtually impossible to undertake research "that is uncontaminated by personal and political sympathies" (Becker, 1966, p.239). No matter how we try to achieve neutrality, the researcher can never be totally silent or objective because "research in any human environment without subjective feeling is almost impossible" (Liebling, 1999, p.149). As to whether interviewees hesitated in their answers because of my previous position, I knew only some students, and those I did, I would not have had any contact with for at least two years. As the following section shows, the answers were varied and did not necessarily reflect what they perceived I wanted to hear.

Prison education in Ireland is based on two major influences: Council of Europe policy and the "principles of adult and community education," offering a broad flexible programme. The objectives are varied and include helping people "cope with their sentence, achieve personal development, prepare for life after release and establish the appetite and capacity for lifelong learning" (Irish Prison Service, 2011, p.22). Following Council of Europe (1990, p.4) policy on education in prison, it strives to "develop the whole person bearing in mind his or her social, economic and cultural context" which recognizes the marginalization and alienation that many prisoners endure both inside and outside the institution. Educational provision is provided through a partnership with a number of outside agencies, primarily City and County Educational and Training Boards (local education authorities).

Adults engage in education for a variety of reasons. Some do it to acquire knowledge and learn a skill. Others embrace the opportunity of a second chance education or to continue lifelong learning. A number get involved to pass the time, take their mind off other issues, or in the hope of personal or even political transformation (Thompson, 1996). The interviews revealed that the reasons many prisoners participate in education mirror somewhat the range of motivations of adults outside. However, there are aspects unique to their location: loneliness, isolation, boredom and attempts to create an alternative routine to the one set out by the institution. Some sought to maintain their pre-prison individuality and others wished to use their time to develop a new identity.

The reason/s for participation in education was, for many, multi-layered. The interviewees tended to identify a primary purpose for their participation but also listed a number of other reasons. While not being mutually exclusive, four categories were distinguished according to their main reason for participation. The largest group (19 respondents) wanted to pursue a second chance education and up-skill to prepare for employment on release. The next group of 13 interviewees wished to escape the monotony and boredom of the prison regime; seven used education to pass the time and six students saw education predominantly as a space for critical thinking and personal transformation. These motivations are remarkably similar to the categories MacGuinness (2000) found in the responses as to why prisoners began education in prison - to catch up on academic qualifications, keep occupied, improve employment prospects, to survive prison and manage their time inside (p.91). Overall, while various motivations were identified for participating in education in this study, as time went on, perspectives on education developed. For some it was no longer just to pass time, but to prepare for release; for others, they saw the opportunity for personal transformation. The latter motivation was particularly prevalent among those who had been in and out of prison, or spent a longer time in 
prison and seemed more deeply enmeshed in the change process. It could also indicate that they had little option but to adopt an alternative lifestyle and no doubt, the length of time they spent in the institution impacted on their outlook and perspectives.

\section{Preparing for release}

The largest number of respondents attended school to gain skills or acquire knowledge they had missed out on before incarceration. They hoped to prepare for a productive life after prison. It is understandable that this motivated such a large number, as prison populations tend to have low levels of traditional educational attainment. Many have had negative experiences of education and despite internalising this negativity having judged themselves by the system's evaluative process - there was a remarkably high take-up of education. This mirrors the participation rate in prison education in other jurisdictions (see Duguid, 2000; Wilson \& Reuss, 2000).

This group wanted to use their time in prison constructively. Most had left school early, not taken any examinations and wished to engage in what is usually termed adult basic education. They were aware that their lack of education, including qualifications, impacted on their life before incarceration and would limit their opportunities afterwards. They had either been unemployed, under-employed or in low-skilled manual positions prior to incarceration. George was over five years into his life sentence and was representative of this group. Prior to imprisonment, he had completed three years of secondary school and attended school in prison because "I want to improve my writing in English. I want to learn how to work the basics of computers." Oscar was serving life. His motivation was simple: "to get educated. Just want to get educated." Gavin was in the early stages of a life sentence and had been in a blue-collar, low-skilled position prior to imprisonment. He was clear about his reason for participation in education. "I want to equip myself as much as I can, to get ready to go home, back into the workplace. Also it gives me a purpose and it helps the time to pass. And in that order."

This group primarily used their time in prison for utilitarian reasons. They reflected one of the more traditional motivations for adults participating in education outside the institution, to up-skill and prepare for employment opportunities. It also followed a particular understanding of "offender learning" which seeks to "place a much greater emphasis on developing the vocational skills that offenders need to find and keep jobs" on release (Ministry of Justice, 2011, p.7). Deciding to use their time in prison pursuing education was a positive decision. As it was a voluntary activity and would not necessarily impact on the length of their sentence, it indicated they retained a sense of agency and showed that they could still make some choices on how to spend their time in a rule-bound and coercive environment.

\section{Killing time}

The next two groups have similarities in their use of education, primarily, as a coping strategy. Perhaps unconsciously, it was a way of limiting the damage the institution was doing to them. Interviewees were explicit that their time in prison was to be endured, and to take their mind off the place, they took part in education. Prior to incarceration, they had different levels of education and did not necessarily attend school to gain skills and/or increase knowledge. Daniel was coming towards the end of his seven year sentence and his response was characteristic of this group. Echoing one of the objectives of the Irish prison education service which include helping students cope with their sentence, he asked: "Truthfully?" when questioned about his motivation behind participation in education. "To kill the time. That would be the first reason. To better myself and become more informed. To get an opportunity to indulge in hobbies". Admitting that "you haven't too many options in here," it was for Enda, who was serving over six years, "a change. It passes the time."

Isaac was nearly half way through a six year sentence. He had left school at 14 and admitted that he needed to work on his literacy skills. He attended school "because there is nothing else to do. Because if I don't, I get bored, just sitting around all the week. So I go up to the school every Wednesday and it passes an hour and a half in. Just to get out of the workshop, to pass the time in." Callum had only recently begun a two-year sentence (although he had been in prison before). He hoped to study for an undergraduate degree. "I am a natural student. It greatly passes the time for me in prison. It makes it more short if you are studying."

\section{Escaping from the prison}

Inter-linked with the motivation of the previous group, many of the students in this cohort used the opportunity of education to try to break away from the prison routine. They identified involvement in school as part of the process of adaptation to their new surrounding and as a coping strategy. Archie was less than a year into his four year sentence. He had a variety of reasons for attending school. "The reason why I go to school is just to get out of the workshop. Rather than work down there, I come up here [to school]." But he also "enjoyed it up here anyway because it's a way of escaping from the prison too. And the time I spend in the education programme doesn't feel like prison to me."

Hugh was coming towards the end of a sentence of over 15 years and perhaps mindful that it was a teacher (although not teaching in prison at the time) undertaking this research, seemed somewhat embarrassed about expressing the sentiment echoed by many other prisoners about why they got involved in education. He simply wanted to escape the daily drudge of the regime. He had completed two years of a science degree before prison but had to leave due to family circumstances. While he now had "opportunities to do courses in the prison," he set out his motivation for attending school: 
"I suppose because...I had a good level of education, right, I suppose, I do come over to learn. How do I put this without sounding....Sometimes I come over as a distraction from the prison." Luke, with nearly a third of his nine-year sentence complete, was studying a wide range of subjects including English, Drama, and Arts and Crafts. "Honestly?" he asked when questioned why he attended school: "it was just to get out of the prison, originally. And because you are treated with more dignity and respect." However, he conceded that he was now moving towards a more considered approach to education. "As I got older and a little wiser, I realised the benefits of it. I think it is one of the most priceless gifts that you could have - education."

While educators within prison attempted to generate a different culture within education departments (see Behan, 2007; Costelloe \& Warner, 2008), there is a key distinguishing element of the "pedagogical relation: creating an atmosphere" (O'Donnell, 2013, p.278; see also MacGuinness, 2000 and Smith, 2013). William was one third through his 15 year sentence and seemed to identify with this. He wanted to "get away from prison. You are away from prison, you know. To get out of your cell, the workshops. For an education, to stop you from sinking. It's nice to be with teachers as well, from the outside. To get a bit of trust, you don't get a lot of that."

Similar reasons were given to MacGuinness (2000) who reported that students preferred the atmosphere in the school than the prison wing or workshop, with one respondent pointing out that the six months he spent in the workshop was "tedious" (p.101). Crewe (2012) in his research in Wellingborough prison found that within the education department, "many prisoners found sanctuary from the stresses of life on the wings and from the normal terms on which staff-prisoner relations were founded." Prisoners often commented to him that the education block was "one of the few zones within the institution that didn't 'feel like a prison"” (p.119).

Students felt there was a different ethos in the school. The employment of non-prison staff is possibly the feature that distinguished the educational space from the penal environment most acutely. As teachers are employed by local education authorities, they bring pedagogical principles to their practice. Teachers who come into daily contact with prisoners tend to protect their independence within the system. The use of nonprison staff contributes to the creation of a different atmosphere and culture in the school. Prison teachers lack the disciplinary rationale of prison officers or the correctional goals of programme staff. They were considered differently by prisoners to others who worked in the institution. This allowed for a more informal environment in the school. Students appreciated being called by their first name and addressing teaching staff in a similar manner. This made it easier to create a space for co-operative endeavours, based on prisoners as students rather than students as prisoners. This group of students identified the school a place apart from the prison, based on a different ethos and atmosphere.
These two groups used education as one of the "removal activities," which "mercifully kill" time in contrast to the "ordinary activities" which in prisons "can be said to torture time" (Goffman, 1961, pp.67-8). Prison schools may be a place where the individual can get lost, a temporary blotting out of all sense of the environment in which they live, a little island of "vivid, enrapturing activity" in the "kind of dead sea" of the institution (Goffman, 1961, p.68). While the regimefocussed and rule-bound late-modern prison may seem to work against the basic tenets of education and change, these findings suggest that prisoners retained some sense of agency as they utilised the facilities to overcome the structural constraints of the regime and voluntarily engage in a practice associated with freedom. They felt that while they were in school, they were outside the norms of the disciplinary objectives that influence their daily life in prison. While some prison schools are physically located in different buildings to the rest of the prison, students believed the ethos and atmosphere was detached from the prison because of the space it offered to express their individuality in a non-threatening, trusting, and even potentially, a non-penal oasis.

\section{Transformation}

The final group had either spent numerous periods in and out of prison, or were serving a long prison sentence. They came from a mix of educational backgrounds. They tended to be older and began to appreciate how education could help them to move away from a life of crime. However, few initially came to school with this in mind. Ryan, serving seven years, believed there was "no harm in a person getting professional educational tuition. If it wasn't there [in school], I would probably still be studying, but probably in the prison cell." But there was a deeper motivation:

I think when a person comes to prison there is a long time to reflect on their past, present and future. When a person ends up in prison, irrespective of the length of time, there is something wrong in that person's life, prison gives a person an opportunity to change and I think education is a main factor in a person changing.

Samuel had just begun a life sentence and this had forced him to re-assess his life. When interviewed he was in a contemplative mood, questioning his life before prison. He was in the first year of a social science degree with the Open University. While he was "interested in issues, social issues, environmental issues," he felt that "lack of education would have been a factor that led me to prison." For him education made "prison life more bearable, a lot more bearable." However, perhaps more significantly, it was part of a process of change, and of "making good" (Maruna, 2001). It was an "opportunity, one of the few ways I can make amends to society, to my victim. It is one of the few ways to make amends, some form of amends."

Martin had been in and out of prison since his teens and had initially begun school to get away from the prison regime and routine. He explained how he began 
encountering words such as restorative justice, rehabilitation and punishment, not having understood or considered their meaning before taking a course in criminology. Admitting that he was perhaps biased, he acknowledged that "at first I could not identify with my victims because I always considered myself to be a victim." He believed that "after being a part of the prison system for over the last 20 years of my life, jail was never a deterrent for me" and came to realise that "in prison...there was very little rehabilitation." After a period of reflection:

I decided to go to school initially to remove myself away from the landing which I found to be very boring and mundane, the majority of my day was being spent hanging around, sitting in other people's cells, drinking tea and talking about stuff that really did not interest me...I wanted to change by means of taking a personal reflection of my life and what I needed to do to change. Education was a major factor in that process as well as doing some other selfhelp, going to the gym, finding spiritual guidance and very little else, because my choices were very limited.

Harold had been in prison a number of times previously and later went on to a period of further study. Initially he did not associate education with a move away from criminal activity. He was deeply cynical of all those who worked within the prison system: officers, programme staff and, initially, teachers. They were all part of the coercive system. While unwilling to participate in any of the rehabilitative programmes on offer, it was only after a period of time in school that he began to change his mind.

Having started classes I found the school staff to be very encouraging which was new to me as I had never been encouraged to do anything positive before...With the exception of those I engaged in committing crimes with throughout my life, it was the first time anyone recognised any potential in me, and I began to enjoy attending classes and engaging in discussions with the teachers and other prisoners. And although I agreed to consider attending college on my release, I, in reality still had no intention of ceasing committing crime. It did however leave an impression on me. One of the teachers in the school gave me an article which was written by a prominent criminologist, which sparked my interest in the subject, and changed my view of academics which I had previously viewed in the same light I had viewed the prison service. As a result of my up bringing I had a very clannish mentality and I held this view of anyone who didn't come from a similar background to myself, treating them with a deep suspicion.

Harold and this group of students were perhaps further on their way towards personal change. While initially not setting out on a journey of transformation, education was an integral (although not the only), part of that process. This group of students indicated an interest in and concern for the world around them, partly inspired by their participation in education. In common with all other groups they were co-operating with each other in a positive engagement, based on a productive collaboration indicating that these students were developing social and human capital. As they participated in educational programmes voluntarily, they developed at their own pace, on their own terms, not on a pre-determined structured framework set out by courts, state or in some rehabilitative programmes.

\section{Agency and Change}

Imprisonment is generally about limiting autonomy and responsibility, two key ingredients in a successful pedagogical process. Nevertheless, this study indicates that students retained some agency, firstly by deciding to attend school voluntarily - even if it was for some simply to make their time in the institution more bearable - and secondly by participating in an environment based on a different culture than that which tends to pervade within the prison. Several students used their time in prison to reflect on their past activities, the hurt they have caused to others, hoping for a different future, away from a life of crime. Wilson (2007) found that some students "counter the effects of incarceration by incorporating and/or modifying aspects of their outside world into the prison setting" (p.199). In this study, Gavin was involved in the Listener Scheme (the prison equivalent to the Samaritans); Ryan had participated in charitable fun runs and others were involved in the various fund-raising activities in the prison. Some students began to adopt a different self; others reasserted somewhat their identity prior to incarceration.

For some students, participation in education was part of a transformative learning process which is consciously or sub-consciously:

becoming aware through critical reflection of the frame of reference in which one thinks, feels, and acts. It involves becoming aware of its genesis in one's individual history and/or culture, the search for a new more developed frame, and acting on the ba sis of the new frame of reference (Fleming, 2002, pp. 3-4).

The process of transforming frames of reference begins with critical reflection. This was certainly the case for Martin, Harold and others in this group. Engaging in transformative learning encourages not just desistance from criminal activity, which is the underlying objective of many contemporary rehabilitative programmes, but locating laws in wider contexts, understanding the social construction of criminality, and considering issues around punishment, class and economic (in)justice. Such an approach challenges the imprisoned to become reflective agents for change outlined in Rotman's (1986) "anthropocentric" rehabilitation model, rather than complying with the demands of correctional agendas or the "authoritarian" rehabilitative programmes. It also encourages agency and recognizes that authentic transformation cannot occur without an individual's voluntary participation.

While the initial motivation to engage in education among several respondents might seem to be somewhat limited, nevertheless attending school is not a goal in 
itself; it is the initial step on an educational journey, which is without a doubt a process, and may or may not end on completion of their sentence. Richards and Jones (2004), both former prisoners and proponents of convict criminology, believe that when an individual is committed to prison, s/he descends, however, "if he or she can muster the intellectual or spiritual desire to remake him or herself, he or she ascends from the shadows to re-join the world." However, this is not an easy process as they argue, to "transcend the prison experience, a person must honestly understand who he or she is and who he or she wants to be, and do the work to accomplish that change" (p.227). For some students education is part of the process of/or towards ascent. It gives them an opportunity to participate in an environment based on a different culture than that which pervades in many prisons. Those who were engaging in education for more utilitarian purposes were choosing a productive activity within a limited structural context. This indicated that many retained their agency, which allowed them to assert some autonomy, even within the rather restrictive rule-bound and regime-focussed institution. This study suggests that education helped students cope with their sentence, adapt to prison life, learn new skills, and for some students, potentially it was part of a process towards personal transformation.

\section{Prison Pedagogy and Penal Policy}

The testimonies from interviewees indicate the diverse motivations for student participation in education within prison. They also reveal that there is a complex dynamic not just in meeting the needs of the learner group, but also creating a learning environment in a coercive environment. In analysing the challenge of creating the space for a transformative learning experience, Paul Kirk, Education Manager at Guys Marsh Prison in England, described the essence of this undertaking:

I believe that prisoners - especially those on longer sentences - are asked to undergo the most difficult of all human processes, the process of change, often in a deeply unsupportive environment. Prisoners, usually via their sentence plans, are made to ask themselves the great existential questions that most of us only encounter in moments of great stress and turmoil - who am I, where am I going, what's the point of my existence, what's wrong with the way I live, what do I need to change, what's the point of it all? These are questions that no doubt anybody sent to jail asks themselves at some stage and in many cases they are questions that may well need to be addressed by people living destructive and selfdestructive lives. But they are not easy and they demand a level of self-awareness that evades many people in the general population. (Kirk, 2012)

The sites of all education can be ambiguous, but there are some challenges unique to the provision of education in prison. Education is not a neutral technology that can be separated from the context in which it takes place. The prison environment is "often bleak and anti- thetical to the educational mission" (Gehring \& Eggleston 2006, p.xii) and the potential to create the space for learning is influenced, by among other factors, the nature of prison itself, the conditions of confinement and institutional dynamics. Other considerations include the educational level of the learner group, increasing managerialism, attempts to re-define education with the ascendancy of cognitive skills-based courses and "offender learning" programmes and the challenge of finding an appropriate means of measuring outcomes and evaluating change inside.

The rigidity of the daily routine is central to imprisonment. Robert McCleery (1961, p.154) pointed out that "the heart of custodial controls in traditional prisons lies in the daily regimentation, routine and rituals of domination which bend the subjects into a customary posture of silent awe and unthinking acceptance." While the extent to which prisoners are bent into compliance may be exaggerated, the general point about the corrosive effect of routine is well made. Critical thinking can only develop when we accept that the process will be uncomfortable, ambiguous, tentative, uncertain and evolving (Brookfield, 1987). However, prisons have a tendency to create regimes where prisoners can "find the maintenance of behavioural boundaries satisfying, because it implies exemption from difficult choices and personal responsibility for one's plight" (Mathiesen, 1996, p.371). Ironically, the lack of responsibility provides safety in the comfort zone. There is little opportunity for ambiguity, uncertainty or feelings of insecurity in such a stifling routine. The process of transforming frames of reference begins with critical reflection, with assessing one's own assumptions and presuppositions. To engage in critical reflection usually leaves one uncomfortable and challenged (Mezirow, 1996). It seems that traditional prison regimes create an environment that must work against this. Regime and routine can undermine the potential to put students in an uncomfortable place where they have the space and support that Kirk suggest is needed for the process of change and transformation.

While institutions certainly have an impact on prisoners (Sykes, 1958; Goffman, 1961), individuals also bring in attributes (Irwin \& Cressy, 1962) to the prison. Mindful of the structural context, prison educators should also be careful of expecting too much from prison and must be especially cognizant of the student group. "Prisoners are people who have been failed," with many having a "long history of failure at home, at school, at work," argued the first official report into the penal system in Ireland. Therefore, it concluded, it is "unrealistic to expect that prison can achieve what better-placed institutions in society have failed to do. Neither are prisons like laundries where what is wrong, personally and socially can be washed away" (Whitaker, 1985, p. 91).

Incarcerated populations throughout the world are overwhelmingly young, male and from poor socioeconomic backgrounds. Ireland is no different as the "prison population is characterised by multiple forms of socio-economic disadvantage," and communities 
with the greatest indices of deprivation bearing the "greatest burden of imprisonment" (Rogan, 2013, p. 98). These communities are rife with unemployment, low wage jobs, drugs, crime and marginalisation, with high levels of poverty and low levels of traditional educational attainment. The latest research on literacy levels among Irish prisoners indicates that nearly 53 per cent were in the level one or pre-level one category (highest is 5) and that the average literacy level of the prison population was much lower than the general population (Morgan \& Kett, 2003, pp.35-36). Similar levels of educational disadvantage have been found among prisoners in other jurisdictions (for the United Kingdom, see Prison Reform Trust, 2013 and for the United States, Muth, 2005). An analysis of punishment, social deprivation and the geography of reintegration in Ireland found that one per cent of electoral districts accounted for nearly 24 per cent of prisoners, but less than five per cent of the population. It concluded that in general, "prisoners were at least three times as likely to come from the most, as compared to the least, deprived areas" (O'Donnell et al. 2007, p.2). The lived experience of prisoners, both prior to and during their incarceration is a key element to understanding the dynamics of educational development and particularly important in meeting the needs of the learner group.

\section{Redefining education}

In an effort to make prison education more politically acceptable, attempts have been made to redefine it into psycho-educational or psycho-social programmes (O'Donnell, 2013; Smith, 2013), cognitive courses to deal with "offending behaviour" as happened with the demise of the humanities programmes in Canada (Duguid, 2000). Educational programmes "are increasingly colonised" or being replaced by courses in life skills, communication skills, anger management, etc. (O'Donnell, 2013, p.271), with one teacher reporting how, in order to continue teaching philosophy in an English prison, he was forced to call it Advanced Thinking Skills on the forms for educational managers (Smith, 2013, p.71). Reframing education as treatment reduces the individual to a patient, a subject, somebody that something is done to, rather than with.

Participation in "offence-focused" programmes as part of the authoritarian rehabilitation process identified by Rotman which are ordered by the courts or essential for early release can give the appearance of change through conformity, rather than an authentic personal transformation. Some of these programmes, especially those run by the prison, have been criticised as attempts by the state to "responsibilize," "redeem," or "normalise" the socially excluded (Ryan \& Sim, 2007, p.697). According to Costelloe and Warner (2008) these programmes are based on "a limited and negative approach" which follows the "discredited medical model of imprisonment." It begins with an ethos that "views the prisoner primarily as something broken in need of fixing or as an object in need of treatment" (p.137). Many offending behavior programmes within contemporary rehabilitation models concentrate more on "themes of personal responsibility, choice and recognition of the moral implication of these choices" (Robinson and Crow, 2009, p.121) to the detriment of the social context of criminality and punishment.

For long term prisoners, especially lifers, participation in these courses are generally mandatory, and the process of achieving freedom early has become more complicated, even perplexing, leading to those with "psychological power" (Crewe, 2012) wielding enormous influence. While there are "serious questions of justice to be asked about relating the length of time a person spends in prison to the degree to which he or she co-operates with or is involved in such activities" (Coyle, 2008, p.230), programmes that are mandated by courts, prison system or parole board and deemed necessary for release can be particularly problematic. Similar to the experiences relayed to Crewe (2012) and Maruna (2011) many interviewees in this study had an aversion to courses provided by the prison, especially psychological and offenderbehaviour programmes. None of those interviewed saw education as a part of a process of "rehabilitation" or even used the word (except for Martin who began to appreciate the meaning of the concept in a criminology class). They seemed to have no investment in the concept, considering it rather as a professionalised process, where they follow frameworks set out by the prison system, which immediately made them wary. Interviewees distinguished school activities from prison programmes and were eager to stress that it was a place for them, not for the prison. Prison education organised and run by outside educational bodies allows for greater flexibility than the regime determined routines that are usually associated with incarceration or prescribed outcomes of many rehabilitative programmes.

Nevertheless, despite their limitations, dismissing all courses provided by, or within, prison means that some prisoners will miss out on an opportunity to participate in activities that address issues such as addiction that have blighted their lives and led to criminal activity. If students voluntarily participate in prison programmes, this can be an important step before they consider other questions that may need addressing in their life. Some courses not only deal with the issues that led to their "offending" behaviour as desired by the state but help them face up to their transgression of the rights of others. The effect may be far more liberating for both the individual and society than the intention. While Reuss (1999) rightly stresses that there is still an underlying concern that such courses may be helping the prison rather than the prisoner, she argues, "there is perhaps a need to synthesise the 'best' elements of these courses with the 'best' of traditional education" (p.123).

\section{Measuring outcomes and calculating change}

Prison pedagogy, similar to other areas of education, finds itself in the murky business of measurement and evaluation. Reuss (1999) was asked when conducting her research: "'How can you show it?' or 'How do you know they've changed?"' (p.114). Perhaps we could 
begin by recognising that pedagogy is not a science, rather an art. What works for some may not for others. And what works at one point in a sentence may not be appropriate during a different phase. If we are to attempt to measure the effectiveness of transformative education - which is practically impossible - it is more beneficial to examine process rather than outcome. In this endeavour, process can become the outcome. An awareness of students' motivations behind participation in education outlined in this research indicates that traditional methods of assessment usually associated with utilitarian objectives are unsuited to students in prison. An analysis of prison education could utilise criteria in areas such as problem solving, listening and communication, critical reasoning, teamwork, application to tasks, activities which usually indicate that an individual is developing social and human capital. These are not easily measurable, rarely linear, take time and effort, and cannot be reduced to formulae and inappropriate methods of determining success or failure of human beings with complex histories and multifarious issues.

Adult education is more than just the accumulation of knowledge or the acquisition of skills; it seeks to locate learning in a wider social context. As most of those interviewed for this study were not overly-concerned with achieving grades in examinations, this allows for more flexibility and creativity than is usually associated with traditional education approaches and outcomes. Thomas (1983, p.231) found that education in prison "both subverts, yet stimulates teaching strategies" which are open to educators to develop. As happens in Irish prison education, a wide curriculum and a range of activities allow individuals to work to their strengths. This could mirror somewhat the "strengthsbased practices" involved in the desistance process, which assess the positive contribution, rather than the deficits, of individuals and "provide opportunities...to develop pro-social self-concepts and identity" (Burnett \& Maruna, 2006, p.84).

While there are debates over the most appropriate method of evaluation, educationalists should be careful about getting drawn into using the recidivist rate as one of the indices of change. If education uses the recidivist rate to judge progress (Esperian, 2010), this is a rather crude and unsuitable method of measuring outcomes or characterizing change. Evaluating the impact of both rehabilitative programmes and educational courses on desistance from crime is a near impossible task. Data on participation in both Reasoning and Rehabilitation courses and prison education indicate lower levels of recidivism, and graduates of these courses were found to have higher levels of personal stability, evidence of social change and greater rates of employment in comparison to others who do not participate (Duguid, 2000; Esperian, 2010; Haulard, 2001; Ministry of Justice, 2010). However, results from both rehabilitation and educational programmes must be interpreted cautiously as those who have voluntarily signed up to these activities already indicate a desire to change and the impact of participation on their perspectives and future activities is difficult to measure.
Change does not occur in a vacuum. Motivation to change and attempts to create a better life are not always simply down to the individual's desire for transformation. Burnett and Maruna (2004) found prior to their release, $80 \%$ of persistent offenders said they wanted to "go straight," but only $25 \%$ believed they would definitely be able to do so (p.395). Building human and social capital supports and reinforces efforts to move away from a life of crime, but many prisoners and ex-prisoners have "low social capital and have to work hard to achieve a successful conventional life" (Healy, 2010, p.180). Developing social and human capital can be a challenge in any environment, especially in a prison. Nevertheless, individuals cannot be separated from the context in which they are located, nor their social, economic and educational background.

There are many reasons why an individual decides not to commit a crime. For those who participate in education, this has been a significant factor in their desistance (Wallington, 2014). Nevertheless, while governments and prison systems may be concerned with determining effectiveness of education in terms of recidivism, crime reduction and value for money (Ministry of Justice, 2011), it is inappropriate to judge success or otherwise by a methodology unsuited to the complex development of human change. Education is a much more sophisticated process. It has similarities with why, how and when people desist from crime which "resides somewhere in the interfaces between developing personal maturity, changing social bonds associated with certain life transitions, and the individual subjective narrative constructions which offenders build around these key events and changes" (McNeill, 2006, p.47). Accordingly, "It is not just the events and changes that matter; it is what these events and changes mean to the people involved" (McNeill, 2006, p.47).

Education can and should mean different things to different people. As the interviewees in this study indicated, it can mean different things to the same people at various points in their educational journey and life course. Analysed in this framework, education can play an important role in encouraging an individual to move away from a life of crime, not just to desist from breaking the law, but developing social and human capital essential to achieve this, and contributing to their community after they have served their time. Linking education to measurements around recidivism and rehabilitation can corrode the integrity of education, especially as educational programmes in prison settings "often operate within shifting policy environments and are themselves frequently the subject of contest and controversy" (Higgins, 2004, p.246). If prison education is not to follow changing penal ideologies, or get embroiled in "authoritarian" rehabilitation agendas, it must, define its own objectives based on educational principles and be cautious about adopting or adapting to the vagrancies of changing penal policy if these are inimical to the objectives of pedagogy.

\section{Conclusion}

A more comprehensive consideration of the potential 
for transformation and change within prison is enhanced by understanding the motivations behind student participation in education. This article has set out some of these which include learning new skills, adapting to the prison, using it as an opportunity to escape the monotony of the routine and regime and for some, using their time in prison for personal change and transformation. While a number of interviewees were acutely conscious of the importance of education in the process of change and transformation, even the students who utilised education to develop skills and prepare for release indicated that they retained a sense of agency within the structural constraints of a coercive institution. Therefore, prison education should continue to consider how to help students cope with their sentence, limit the damage that the institution does to them and reflect on how to build on students' strengths. It could also explore how to develop the rather ambiguous and complicated process of building human and social capital. These are not the instrumentalist indices of change that underpin authoritarian rehabilitation or more traditional educational measurements, but may be more authentic indicators of change and transformation.

While this article has argued that mandated authoritarian rehabilitative programmes are problematic when determining change and authentic transformation, it recognises the potential for these programmes to effect change in learners' sense of agency. Recognising that mandated rehabilitative programmes can lead to the appearance of, rather than real change, there may be positive elements within rehabilitative programmes that recognise and try to heal the damage that criminal activities have done to prisoners themselves and their fellow citizens. However, education, while potentially finding an accommodation with rehabilitation programmes, should continue to distinguish itself from these programmes. Prison education operating in an era of authoritarian rehabilitation could mirror adult education models in the community which works best outside of the mainstream, sometimes even against the dominant discourse, on the margins. Even though it may be funded by the state, adult education has worked as a more transformative experience when it has maintained a distance from the state. Much of the best adult education in civil society creates space for dialogue to deliberate on where individuals find themselves, the type of world they wish to create, and discuss the mechanisms to build a fairer society (Fleming, 2007).

Despite the idealism of early reformers such as Elizabeth Fry, there have always been challenges of trying to create space for change in coercive environments (Gehring \& Rennie, 2008, pp.67-8). It is worth remembering that the past was no means a utopian place. Even in the halcyon days of penal welfarism, when it held such great potential, "the prison did not much rehabilitate" (Wacquant, 2001, p 124). The present is perhaps less dystopian than we are sometimes led to believe. The study of penal history indicates that rarely were there simple, clear and neat boundaries between penal eras (Loader \& Sparks, 2012). Amid the straitjacket of penal periods, there were always ideas and trends that challenged the dominant discourse. Perhaps in the present, when authoritarian rehabilitation is in the ascendancy, prison education is one of those developments. This study indicates that even in the contemporary prison the potential for transformation and change remains.

\section{Acknowledgements}

I would like to thank the anonymous reviewers for their helpful and constructive comments. I am grateful to Kevin Warner, Jennifer Sloan and Gwen Robinson who read and made suggestion on earlier drafts of this article. All opinions and errors are my own.

\section{References}

Becker, H. (1966). Whose Side Are We On? Social Problems, 14(3), 239-247.

Behan, C. (2008). From Outside to Inside: Pedagogy Behind Prison Walls. In R. Wright (Ed.), In the Borderlands: Learning to Teach in Prisons and Alternative Settings $\left(2^{\text {nd }}\right.$ ed.). San Bernardino: California State University.

Behan, C. (2007). Context, Creativity and Critical Reflection: Education in Correctional Institutions. Journal of Correctional Education, 58 (2), 157-169.

Brookfield, S. (1987). Developing Critical Thinkers: Challenging Adults to Explore Alternative Ways of Thinking and Acting. Milton Keynes: Open University Press.

Burnett, R. \& Maruna, S. (2004). So "prison works" does it? The criminal careers of 130 men released from prison under Home Secretary, Michael Howard. The Howard Journal, 43 (5), 390-404.

Burnett, R. \& Maruna, S. (2006). The Kindness of Strangers: Strengths-based Resettlement in Theory and Action. Criminology and Criminal Justice, 6, 83106.

Carrigan, J. (2013). Prisoner Learners' Perspectives of Prison Education within the Total Institution of the

Prison: A Life History Methodological Approach (Unpublished doctoral dissertation). St. Patrick's College, Dublin.

Cleere, G. (2013) Prison education, social capital and desistance: an exploration of prisoners' experiences in Ireland (Unpublished doctoral dissertation). Waterford Institute of Technology, Waterford.

Costelloe, A. (2003). Third level education in Irish prisons: Who participates and why? (Unpublished doctoral dissertation). The Open University, Milton Keynes.

Costelloe A. \& Warner, K. (2008) Beyond 'Offending Behaviour': The wider perspectives of adult education and the European Prison Rules. In R. Wright (Ed.), In the Borderlands: Learning to Teach in Prisons and Alternative Settings ( $2^{\text {nd }}$ ed.). San Bernardino: California State University.

Coyle, A. (2008). The Treatment of Prisoners: International Standards and Case Law. Legal and Criminological Psychology, 13, 219-30. 
Council of Europe (1990). Education in Prison. Strasbourg: Council of Europe.

Crewe, B. (2012). The Prisoner Society: Power, Adaptation and Social Life in an English Prison. Oxford: Oxford University Press.

Davidson, H. (1995). Schooling in a "Total Institution”. Westport, Connecticut: Bergen and Garvey.

Davis, A. (2003). Are Prisons Obsolete? New York:

Seven Stories Press.

Duguid, S. (2000). Can Prisons Work? The Prisoner as Object and Subject in Modern Corrections. Toronto: University of Toronto Press.

Eggleston, C. \& Gehring, T. (2000). Democracy in Prison and Prison Education. Journal of Correctional Education, 51(4), 306-310.

Esperian, J. (2010). The Effect of Prison Education Programs on Recidivism. Journal of Correctional Education, 61(3), 316-334.

Fleming, T. (2000). Habermas on Civil Society, Lifeworld and System: Unearthing the Social in Transformation Theory. Teachers College Record on-line. Retrieved 10 January 2014 from

http://eprints.nuim.ie/1058/1/HabermasTFleming.pdf.

Foucault, M. (1977). Discipline and Punish: The Birth of the Prison. [Translated by Alan Sheridan] London: Penguin Books.

Garland, D. (2001). The Culture of Control: Crime and Social Order in Contemporary Society. Oxford: Oxford University Press.

GHK (2012). Survey on Prison Education and Training in Europe - Final Report. Order 23 of the DG Education and Culture Framework Contract 02/10 - Lot 1. Strasbourg: European Commission.

Gehring, T. \& Eggleston C. (2006). Correctional Education Chronology. San Bernardino: California State University.

Gehring, T. \& Eggleston, C. (2007). Teaching Within Prison Walls: A Thematic History. San Bernardino: California State University.

Gehring, T. \& Rennie, S. (2008). Correctional Education History from $A$ to $Z$. San Bernardino: California State University San Bernardino.

Goffman, E. (1961). Asylums: Essays on the Social Situation of Mental Patients and Other Inmates. London: Penguin Books.

Grayling, C. (2012). Rehabilitation revolution - next steps announced. Retrieved 10 March 2014 from https:/www.gov.uk/government/news/rehabilitationrevolution-next-steps-announced.

Healy, D. (2010). The Dynamics of Desistance: Charting pathways through change. Cullompton: Willan.

Higgins, J. (2004). Sharing sociological stories: reflections on teaching sociology in prison. International Journal of Lifelong Learning, 23(3), 243-57.

Hughes, E. (2009). Thinking inside the box: prisoner education, learning identities and the possibilities for change. In B. Veysey, J. Christian \& D. Maritnez (Eds.), How Offenders Transform Their Lives. Cul lompton: Willan.

Haulard, E. (2001). Adult Education: A Must for our Incarcerated Population. Journal of Correctional
Education, 52 (4), 157-59.

Ignatieff, M. (1978). A Just Measure of Pain: The Penitentiary in the Industrial Revolution, 1750-1850. Macmillan: London.

Irish Prison Service (2011). Annual Report 2010. Longford: Irish Prison Service.

Irwin, J. \& Cressey, D. (1962). Thieves, Convicts and the Inmate Culture. Social Problems, 10, 145-155.

Kirk, P. (2012). Thoughts on Olass 4, Inside Time, October. Retrieved 10 November 2013 from

http://www.insidetime.org/articleview.asp? $\mathrm{a}=1306 \& \mathrm{c}=$ thoughts on olass 4.

Liebling, A. (1999). Doing Research in Prison: Breaking the Silence. Theoretical Criminology, 3, 147-173.

Loader, I. \& Sparks, R. (2012). Beyond Lamentation: Towards a Democratic Egalitarian Politics of Crime and Justice. In T. Newburn, and J. Peay (Eds.), Policing: Politics, Culture and Control. Oxford: Hart.

MacGuinness, P. (2000). Dealing with Time: Factors that Influence Prisoners to Participate in Prison Education Programmes. In D. Wilson \& A. Reuss (Eds.), Prison(er) Education: Stories of Change and Transformation. Winchester: Waterside Press.

Mathiesen, T. (1966). The Sociology of Prisons: Problems for Future Research. British Journal of Sociology, 17(4), 360-79.

Martinson, R. (1974). What Works? Questions and Answers about Prison Reform. The Public Interest, 35, 22-54.

Maruna, S. (2001). Making Good: How Ex-Convicts Reform and Rebuild their Lives. Washington: American Psychological Association.

Maruna, S. (2011). Why do they hate us?: Making peace between prisoners and psychology. International Journal of Offender Therapy and Comparative Criminology, 55, 671-75.

McNeill, F. (2006). A desistance paradigm for offender management. Criminology and Criminal Justice, 6 (1), 39-62.

Mezirow, J. (1996). Adult Education and Empower ment or Individual and Community Development. In B. Connolly, T. Fleming \& D. McCormack, (Eds.), Radical Learning for Liberation. Maynooth: Maynooth Adult and Community Education Occasional Series, No. 1.

Ministry of Justice (2010). Do Cognitive Sills Programmes work with Offenders. London: Ministry of Justice. Retrieved 1 February 2013 from http:// www.swmprobation.gov.uk/wp-content/ uploads/2010/06/What-works-Cognitive-skills.pdf.

Ministry of Justice (2011). Making Prisons Work: Skills for Rehabilitation. London: Ministry of Justice.

Morris, N. \& Rothman, D. (1998). The Oxford History of the Prison. New York: Oxford University Press.

Morgan, M. \& Kett, M. (2002). The Prison Adult Literacy Survey: Results and Implications. Dublin: Irish Prison Service.

Muth, W. (2005). Two ways to assess literacy learners in prison. Focus on Basics: Connecting Research \& Practice, 7(1), 35-39.

O’Donnell, I., Teljeur, C., Hughes, N., Baumer, E. \& 
Kelly, A. (2007). When Prisoners go Home: Punishment, Social Deprivation and the Geography of Reintegration. Irish Criminal Law Journal, 17, 3-9.

O'Donnell, A. (2013). Unpredictability, Transformation, and the pedagogical encounter: Reflections on "What is Effective" in education. Educational Theory, 63, 265-282.

Prison Reform Trust (2013). Prison: the facts - Bromley Briefings, Summer 2013. London: Prison Reform Trust.

Reuss, A. (1999). Prison(er) Education. The Howard Journal, 38, 113-27.

Richards, S. \& Jones, R. (2004). Beating the Perpetual Incarceration Machine: Overcoming Structural Impediments to Re-entry. In S. Maruna and R. Immarigeon (Eds.), After Crime and Punishment: Pathways to Offender Re-integration. Cullompton: Willan.

Rogan, M. (2013). The Irish Penal System: Pragmatism, Neglect and the Effects of Austerity. In V. Ruggiero, and M. Ryan (Eds.), Punishment in Europe: A Critical Anatomy of Penal Systems. Bas ingstoke: Palgrave Macmillan.

Robinson, G. (2008). Late Modern Rehabilitation: The evolution of a penal strategy. Punishment and Society, 10(4), 431-447.

Robinson, G. \& Crow, I. (2009). Offender Rehabilitation: Research and Practice. London: Sage.

Ross, R., Fabiano, E. \& Crystal, C. (1988). Reasoning and Rehabilitation. International Journal of Offender Therapy and Comparative Criminology, 32, 29-35.

Rotman, E. (1986). Do Criminal Offenders have a Con stitutional Right to Rehabilitation? Journal of Criminal Law and Criminology, 77, 1023-68.

Rotman. E. (1990). Beyond Punishment: A New View of the Rehabilitation of Criminal Offenders. New York: Greenwood Press.
Ryan, M. \& Sim, J. (2007). Campaigning For and Campaigning Against Prisons: Excavating and Reaffirming the Case for Prison Abolition. In Y. Jewkes (Ed.), Handbook on Prisons. Cullompton: Willan.

Smith A. (2013). Her Majesty's Philosophers. Winchester: Waterside Press.

Sykes, G. (1958). The Society of Captives. Princeton: Princeton University Press.

Thomas, J. (1995). The Ironies of Prison Education. In H. Davidson (Ed.), Schooling in a "Total Institution". Connecticut: Bergen and Garvey.

Thompson, J. (1996). Really Useful Knowledge: Linking Theory and Practice. In B. Connolly, T. Fleming, and D. McCormack (Eds.), Radical Learning for Liberation. Maynooth: Maynooth Adult and Community Education Occasional Series, No. 1.

Wacquant, L. (2001). Deadly Symbiosis: When Ghetto and Prison Meet and Mesh. Punishment \& Society, 3 (1), 95-133.

Wallington, J. (2014). Prison Education, the Pathways Project and Desistance Theory. Dublin: Unpublished paper.

Ward, T. \& Maruna, S. (2007). Rehabilitation: Beyond the Risk Paradigm. London: Routledge.

Whitaker, T.K. (1985). Report of the Committee of Inquiry into the Penal System. Dublin: The Stationery Office.

Wilson, A. (2007). "I do it to get Away from the Cockroaches": Educentricity and the Politics of Education in Prisons. Journal of Correctional Education, 58, 185 $-2-3$.

Wilson D. \& Reuss A. (Eds.). Prison(er) Education: Stories of Change and Transformation, Winchester: Waterside Press.

Wright, R., ed. (2008). In the Borderlands: Learning to Teach in Prisons and Alternative Settings $\left(2^{\text {nd }}\right.$ ed.). San Bernardino: California State University.

Cormac Behan teaches Criminology at the Centre for Criminological Research, University of Sheffield. His research interests include penal history, prisoners' rights, comparative penology and prison education. Prior to taking up this position, he taught politics and history in Irish prisons for 14 years. He has served on the executive boards of the Correctional Education Association and the European Prison Education Association. 